\title{
Response of Livestock to Riparian Zone Exclusion
}

\author{
LARRY D. BRYANT
}

\begin{abstract}
Fencing has been proposed as the best alternative for rapid restoration of streamside riparian zones. In this study the major portion of the streamside riparian zone was excluded by fencing. Use by cows with calves and by yearlings was evaluated on the remaining portion of the riparian and upland zones during the summer grazing season. Regardless of aspect, both classes of livestock generally selected the riparian zone over the uplands throughout most of the summer grazing season. Both classes of livestock reversed their selection in favor of upland vegetation in the latter part of the season. Slopes less than $35 \%$ were preferred throughout the grazing season. Cows were more selective in use of certain plant communities than yearlings and, contrary to usual findings, distributed themselves over the range better than yearlings. Neither salt placement nor alternate water location away from the riparian zone influenced livestock distribution appreciably.
\end{abstract}

Throughout the Pacific Northwest, riparian zones make up a small part of the total land base, yet receive a disproportionately large part of the resource in forest use (Thomas et al. 1979). Due to the favorable moisture, riparian zones surpass other habitats in terms of productivity and use. Recreation, timber harvest, road and railroad construction, and grazing by both wildlife and domestic livest ock have a dramatic impact on this highly productive zone.

Land managers are under pressure to improve water quality and maintain or enhance anadromous fisheries. The Federal Water Pollution Control Act (1972) requires that by 1983, all waters on public lands will be suitable for recreation and propagation of fish, shellfish, and wildlife; and the elimination of pollutant discharge into navigable water will be required by 1985 . The 1972 Act also stipulates that the Environmental Protection Agency will be responsible for monitoring sources of point and non-point pollution. All animals on open ranges are a potential source of nonpoint pollution.

The literature of range management is essentially devoid of information specific to the management of riparian zones. The impacts associated with livestock grazing in the riparian zone have become a subject of controversy in recent years (Carothers 1977). Potential solutions to preconceived problems are only now being formulated and tested.

Cattle (Bos taurus) prefer the diversity, quality, and succulence of vegetation found in riparian zones (Ames 1977). The relationship between the microclimate of an area and cattle use is not well documented.

The common solution has been to fence livestock out of the riparian zone. This approach is expensive, both in terms of fencing costs and loss of forage. Other less drastic approaches, if successful, would be preferred. This study is part of a larger effort to accumulate information essential to development of livestock grazing systems that could protect riparian vegetation from overuse by cattle.

Author is wildlife biologist, U.S. Dep. Agr. Forest Service, Pacific Northwest Forest and Range Exp. Sta., Range and Wildlife Habitat Laboratory, Route 2, Box 2315, La Grande, Ore. 97850.
The objectives of this study were to:

1. Determine differences in use patterns of yearling cattle and of cows with calves in pastures containing both riparian and upland mountain range plant communities,

2. Evaluate behavioral responses of cattle that are excluded from the riparian zone by fencing,

3. Determine differences in use between yearlings and cow-calf pairs between cover types on north and south aspects, and

4. Determine differences in 1,2 , and 3 above due to the periods within the grazing season (time periods I, II, and III).

\section{Study Area}

The study was conducted in the Blue Mountains of northeast Oregon, on the 12,000-ha Starkey Experimental Forest and Range, $48 \mathrm{~km}$ southwest of La Grande, Union County. The area is normally grazed from mid-June until mid-October by 800 animal units belonging to five permittees. The area used in this study included 345 ha representative of the general mix of upland and riparian zones of the area.

The vegetation is typical of mountainous rangelands of the Blue Mountains and has been described by Strickler (1965) and Driscoll (1955).

Elevations range from 1,067 to $1,524 \mathrm{~m}$. Annual precipitation averages $50 \mathrm{~cm}$, of which $90 \%$ falls as spring and fall rains or winter snow. July and August are the driest months. Frost can occur

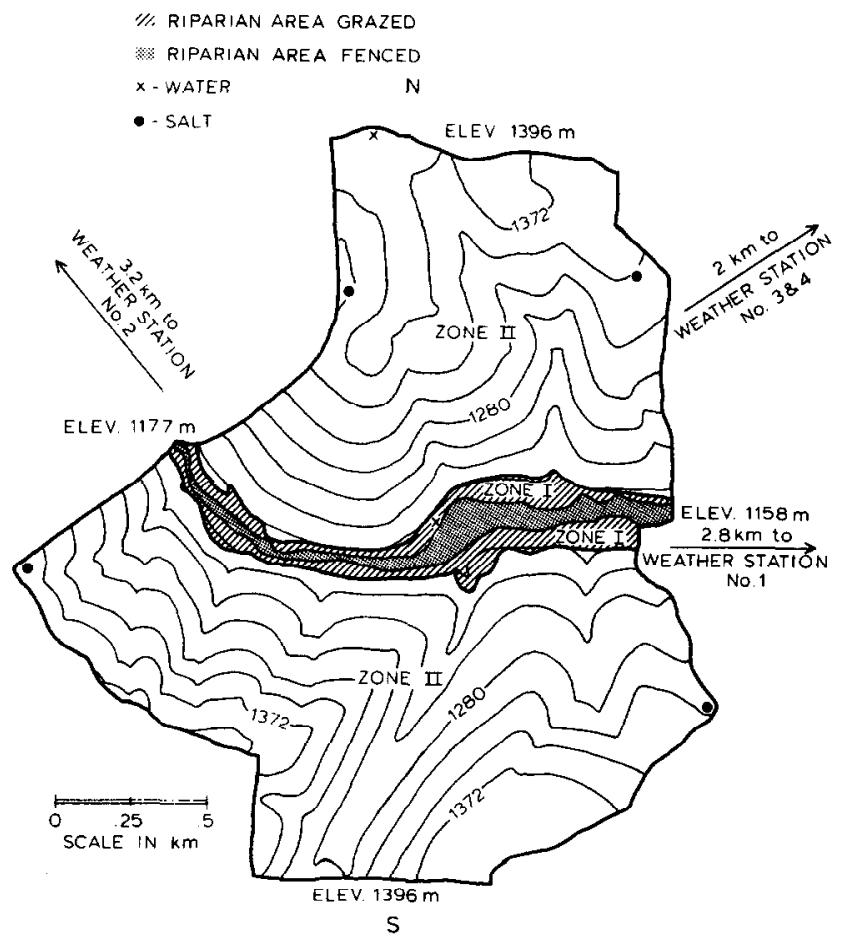

Fig. 1. Outline map of study area. 
during any month (Driscoll 1955).

Soils are predominantly silt loams with parent materials of basalt, ash, basaltic alluvium, and lacustrine deposits. Soil depth varies from $10 \mathrm{~cm}$ on the grasslands to $122 \mathrm{~cm}$ under forests on the north slopes (Soil Conservation Service and USDA Forest Service 1960).

The study area consisted of two pastures separated by a st ream and riparian zone which was fenced into a corridor (Fig. 1). The north pasture comprised 154.32 ha on a south aspect, and the south pasture contained 190.40 ha on a north aspect. Elevations ranged from 1,158 to $1,396 \mathrm{~m}$.

The plant communities within the pastures were defined by Ganskopp (1978) and were grouped to coincide with Hall's (1973) plant communities of the Blue Mountains (Table 1).

The pastures were divided into riparian (zone I) and uplands (zone II). Most of zone I was fenced to exclude livestock. A small strip of zone I remained accessible between the fence and the toe of the slope (Table 1). The remainder of the pastures were included in zone II (Fig. 1). Not all of the vegetation in zone I demonstrated influence of free water, but other environmental factors characteristic of the riparian zone, such as microclimate, were present. The zone I-II boundary was defined by a distinct ecotone between plant community types.

Table 1. Plant communities, their area composition, and their estimated production.

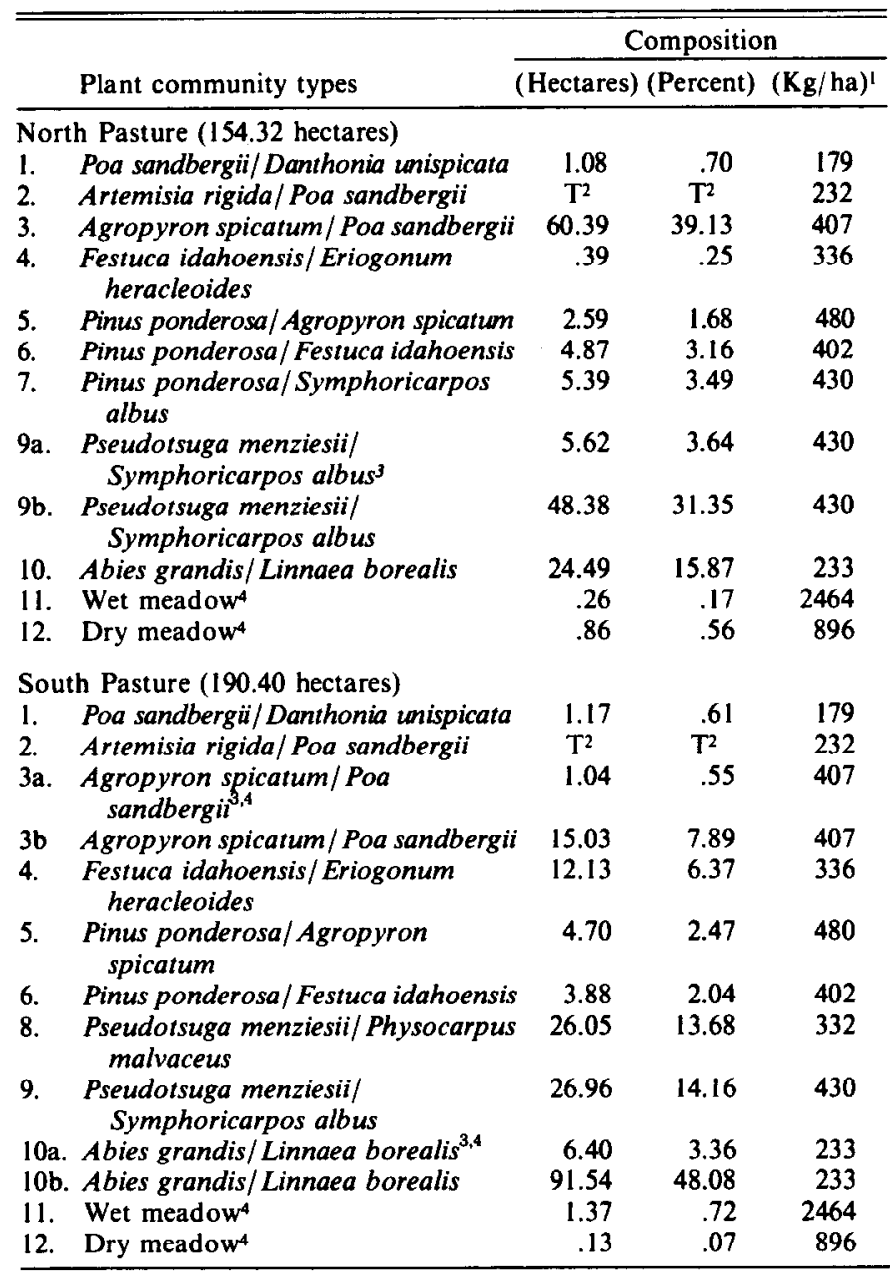

1According to Hall (1973).

2Trace, not measurable.

${ }^{3}$ Although $3 a, 9 a$, and $10 a$ plant communities did not differ in their floristic composition from $3 \mathrm{~b}, 9 \mathrm{~b}$, and $10 \mathrm{~b}$, they were statistically treated as different communities beca use of their location in respect to the riparian zone.

${ }^{4}$ Denotes that these plant communities either occurred in the riparian zone or directly adjacent to it.
Water for livestock was found throughout the south pasture. The north pasture contained two water sources, both constructed ponds. One was located in zone $\mathrm{I}$ and the other on a ridgetop in Zone II (Fig. 1).

Two salt sources per pasture were placed on ridgetops in pasture corners farthest from zone I (Fig. 1).

Weather data were available from four stations located near the study area (Fig. 1). However, only data from stations 1 and 3 that were located under conifer canopy cover were analyzed.

\section{Methods}

The study was designed to determine cattle movements over two aspects, with two classes of livestock, using two different vegetation zones. The grazing season was divided into three time periods (July 20-August 12 (I), August 16-September 9 (II), September 13-October 7 (III)). Three observation days of 6 hours each (0400-1000, 1000-1600, 1600-2200 hours) were conducted in each pasture each week. During these obscrvation days, one animal in each pasture was kept under constant observation and its location was plotted on an aerial photo at 30-minute intervals. Although plotted locations at 30 -minute intervals did not represent totally independent observations, they were treated as such in the analysis.

On June 30, the north pasture was stocked with 10 cows with calves and the south pasture with 15 yearling heifers. The cows were Hereford and Hereford-Angus crosses and the yea rlings were Hereford-Angus crosses. Cattle were rotated between pastures every 2 weeks so they spent equal time in each pasture. The phenological condition and availability of plants to graze remained relatively equal between rotations. Each class of livestock was given a 2-week adjustment period in each pasture before the study began. Thus, the grazing season was divided into 3 time periods with 6 observation days occurring every 2 weeks in each pasture.

Five cows and 5 yearlings were marked with collars to insure identification. One cow and 1 yearling were randomly selected and observed throughout each 6-hour observation day. Monday or Tuesday was randomly selected each week as the starting day. One of the 3 observation days was randomly selected each week, and the other 2 observation days followed in sequence until all 6-hour days were completed. Observations of cows and yearlings in the separate pastures were made simultaneously. Each animal's location was identified as to plant community type, slope, zone, and distance to water and salt.

There are different total numbers of observations (Table 2) between cows and yearlings because of the problem in locating the random selected animal at the start of observation periods.

Chi-square, analysis of variance, and Student's $t$-tests at the 0.10 -level of probability were employed to test hypotheses concerning nonrandomness of distribution of the cattle in response to the previously mentioned independent variables. Chi-square contingency tests were used to test independence between two factors, cows and yearlings. A Chi-square heterogeneity test was uscd to test the randomness of animal response to independent variables. Tukey's separation of means test (Steel and Torrie 1960) was used to differentiate between variables when analysis of variance indicated that differences existed.

The plant community types 1-2, 3-4, 5-6-7 in the north pasture and 1-2-4, 5-6, 8-9 in the south pasture (Table 1) were pooled into larger but still identifiable units because expected values within the types were too small for appropriate use of Chi-square procedures (Steel and Torrie 1960).

\section{Results and Discussion}

The differences in patterns of use between time periods by cows and by yearlings and between cows and yearlings was a response interaction among the vegetation's phenological condition, grazing preference, and climatic changes.

\section{Plant Community Types}

Cows and yearlings spent a disproportionate amount of time in 
Table 2. The observed and $\chi^{2}$ expected values of cows and yearlings in each plant community type (Table 1), in each pasture, in each time period.

\begin{tabular}{|c|c|c|c|c|c|c|c|c|c|c|c|c|}
\hline \multirow[b]{3}{*}{ Plant community types } & \multicolumn{4}{|c|}{ Class of livestock } & \multicolumn{4}{|c|}{ Class of livestock } & \multicolumn{4}{|c|}{ Class of livestock } \\
\hline & \multicolumn{2}{|c|}{ Cows } & \multicolumn{2}{|c|}{ Yearlings } & \multicolumn{2}{|c|}{ Cows } & \multicolumn{2}{|c|}{ Yearlings } & \multicolumn{2}{|c|}{ Cows } & \multicolumn{2}{|c|}{ Yearlings } \\
\hline & Obs. & Exp. & Obs. & Exp. & Obs. & Exp. & Obs. & Exp. & Obs. & Exp. & Obs. & Exp. \\
\hline & \multicolumn{4}{|c|}{ Time period $\mathrm{I}^{\mathrm{l}}$} & \multicolumn{4}{|c|}{ Time period II 1} & \multicolumn{4}{|c|}{ Time period IIII } \\
\hline North Pasture & & & & & & & & & & & & \\
\hline $1-2$ & 0 & 0.3 & 0 & 0.4 & 0 & 0.3 & 0 & 0.4 & 0 & 0.1 & 2 & 0.4 \\
\hline $3-4$ & 1 & 22.0 & 6 & 24.4 & 19 & 22.0 & 0 & 26.4 & 19 & 7.5 & 41 & 24.0 \\
\hline $5-6-7$ & 0 & 4.7 & 1 & 5.2 & 2 & 4.7 & 0 & 5.6 & 0 & 1.6 & 9 & 5.1 \\
\hline $9 a$ & 24 & 2.0 & 27 & 2.3 & 20 & 2.0 & 47 & 2.4 & 0 & 0.7 & 0 & 2.2 \\
\hline $9 \mathrm{~b}$ & 14 & 17.6 & 8 & 19.4 & 6 & 17.6 & 8 & 21.0 & 0 & 6.0 & 9 & 19.1 \\
\hline 10 & 0 & 8.9 & 0 & 9.8 & 0 & 8.9 & 0 & 10.6 & 0 & 3.0 & 0 & 9.7 \\
\hline 11 & 3 & 0.1 & 7 & 0.1 & 2 & 0.1 & 8 & 0.1 & 0 & 0.03 & 0 & 0.1 \\
\hline \multirow[t]{2}{*}{12} & 14 & 0.3 & 13 & 0.3 & 7 & 0.3 & 4 & 0.4 & 0 & 0.1 & 0 & 0.3 \\
\hline & \multicolumn{4}{|c|}{ Time period $\mathrm{I}^{1}$} & \multicolumn{4}{|c|}{ Time period $\mathrm{II}^{\mathrm{I}}$} & \multicolumn{4}{|c|}{ Time period III $^{1}$} \\
\hline South Pasture & & & & & & & & & & & & \\
\hline $1-2-4$ & $\mathbf{0}$ & 4.8 & 0 & 3.4 & 0 & 4.3 & 2 & 4.1 & 11 & 4.5 & 6 & 1.1 \\
\hline $3 \mathbf{a}$ & 15 & 0.4 & 0 & 0.3 & 2 & 0.3 & 0 & 0.3 & 19 & 0.4 & 0 & 0.1 \\
\hline $\mathbf{3 b}$ & 4 & 5.4 & 0 & 3.8 & 0 & 4.9 & 29 & 4.7 & 25 & 5.1 & 7 & 1.3 \\
\hline $5-6$ & 0 & 3.1 & 0 & 2.2 & 0 & 2.8 & 3 & 2.6 & 0 & 2.9 & 0 & 0.7 \\
\hline $8-9$ & 0 & 19.2 & 0 & 13.4 & 0 & 17.3 & 11 & 16.4 & 2 & 18.1 & 3 & 4.5 \\
\hline $10 a$ & 21 & 2.3 & 6 & 1.6 & 15 & 2.1 & 0 & 2.0 & 1 & 2.2 & 0 & 0.5 \\
\hline $10 \mathrm{~b}$ & 26 & 33.2 & 0 & 23.1 & 9 & 29.8 & 14 & 28.4 & 7 & 31.2 & 0 & 7.7 \\
\hline $11-12$ & 3 & 0.7 & 42 & 0.5 & 36 & 0.6 & 0 & 0.6 & 0 & 0.7 & 0 & 0.2 \\
\hline
\end{tabular}

Obs. = Observed

Exp. $=$ Expected value

$\mathrm{t}=$ Significant difference between cows and yearlings $(R<, 10)$.

the riparian plant communities regardless of pasture aspect during time period $\mathrm{I}$. Yearlings and cows used the riparian plant communities again in time period II until they were switched and then both selected the upslope plant communities. During time period III, both livestock classes used the upslope communities extensively but selected different plant communities (Table 2).

Cows with calves grazed the most productive forage areas more widely throughout the entire pastures than did the yearlings (Table 1). Although both classes of livestock had a 2-week familiarization period, the cows had grazed the area in previous years and, therefore, were more familiar with it. Greater grazing familiarity on such ranges may have accounted for the wider distribution of cows than yearlings. Cows with calves have greater (per unit of weight) basal metabolic expenditures than yearlings. Maynard and Loosli (1969) described digestible energy requirements as $2,640 \mathrm{kcal} / \mathrm{kg}$ for cows and $2,310 \mathrm{kcal} / \mathrm{kg}$ for yearlings. There are added energy expenditures for lactating cows. These differences may contribute to the differences in use of plant community types by cows and yearlings. By selecting the more productive plant communities, cows were able to fill their greater energy requirement. Yearlings could evidently fill their lower requirement by remaining on gentler terrain.

On the same study area, Holechek et al. (1978) demonstrated microclimatic effects. He found that cattle weight gains in predominantly forested pastures, during mid-July to mid-September, were $.13 \mathrm{~kg} /$ day greater than those on predominantly grassland pastures. These gains were not solely attributed to the higher nutritional quality of the forage in the forested pastures, but also to the cooler microclimate that allowed them to graze longer each day.

Both cows and yearlings used the timber type plant communities more than the upland grassland plant communities during period II. Besides microclimate, grass and grasslike plants on the forested sites have more crude protein and less lignin than those in grassland pastures during this period (Pickford and Reid 1948, Holechek et al. 1978).

\section{Environmental Conditions}

Differences between stations 1 and 3 in mean daily ambient temperature and mean percent relative humidity recordings were tested by Student's $t$-tests (Fig. 2). During period I, there were differences in mean ambient temperature $(\mathcal{P}<.001)$ and mean percent relative humidity $(P<.001)$ between stations 1 and 3 . During period II there was also a difference between stations in mean ambient temperature $(P<.10)$ and mean percent relative humidity $(P<.001)$. During period III, however, there was no difference between stations in mean ambient temperature $(P<.10)$ while there was a difference in mean percent relative humidity $(P<.001)$.

There was a difference in zone selection between cows and yearlings (Table 4). Yet, during periods of higher mean ambient temperature and lower mean relative humidity on the upslopes, both classes moved to zone I regardless of pasture aspect. When the mean ambient temperature decreased and the mean-percent rela-

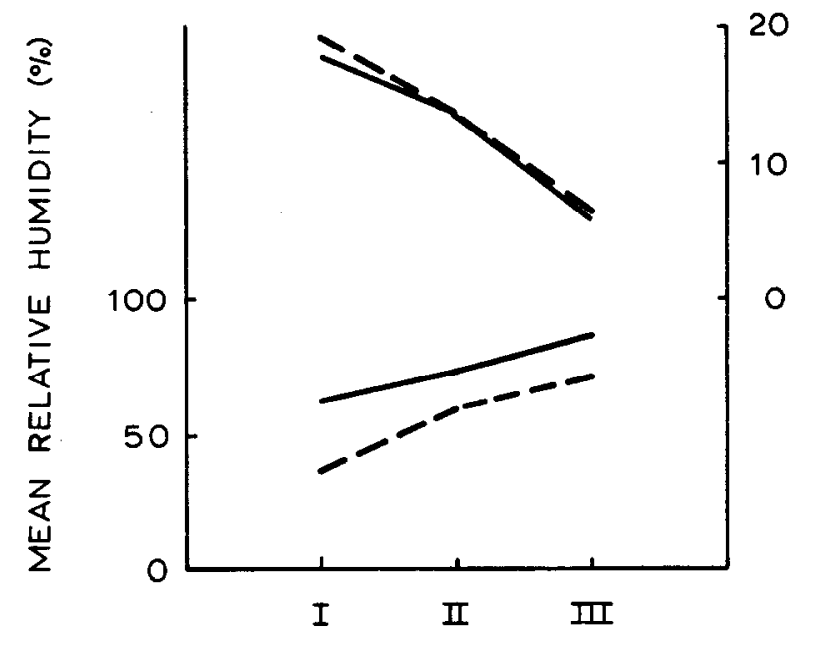

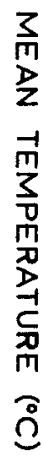

STATION 1

ITATION 3 - -

Fig. 2. Mean temperature and relative humidity by sample periods. 
Table 3. The observed and $\chi^{2}$ expected values of cows and yearlings in each slope class, in each pasture, in each time period, and the amount of pasture in slope class percent.

\begin{tabular}{|c|c|c|c|c|c|c|c|c|c|c|c|c|c|}
\hline \multirow[b]{3}{*}{ Slope classes } & \multirow{3}{*}{$\begin{array}{c}\text { Percent } \\
\text { of } \\
\text { pasture }\end{array}$} & \multicolumn{4}{|c|}{ Class of livestock } & \multicolumn{4}{|c|}{ Class of livestock } & \multicolumn{4}{|c|}{ Class of livestock } \\
\hline & & \multicolumn{2}{|c|}{ Cows } & \multicolumn{2}{|c|}{ Yearlings } & \multicolumn{2}{|c|}{ Cows } & \multicolumn{2}{|c|}{ Yearlings } & \multicolumn{2}{|c|}{ Cows } & \multicolumn{2}{|c|}{ Yearlings } \\
\hline & & Obs. & Exp. & Obs. & Exp. & Obs. & Exp. & Obs. & Exp. & Obs. & Exp. & Obs. & Exp \\
\hline & \multicolumn{5}{|c|}{ Time period $\mathrm{I}^{1}$} & \multicolumn{4}{|c|}{ Time period $\mathrm{II}^{2}$} & \multicolumn{4}{|c|}{ Time period $111^{2}$} \\
\hline 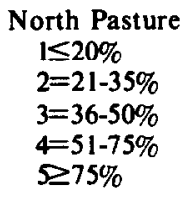 & $\begin{array}{l}21.5 \\
33.2 \\
22.3 \\
23 \\
t\end{array}$ & $\begin{array}{r}41 \\
0 \\
11 \\
4 \\
0\end{array}$ & $\begin{array}{r}12 \\
19 \\
12 \\
13 \\
0\end{array}$ & $\begin{array}{r}41 \\
13 \\
1 \\
7 \\
0\end{array}$ & $\begin{array}{r}13 \\
21 \\
14 \\
14 \\
0\end{array}$ & $\begin{array}{r}29 \\
10 \\
15 \\
2 \\
0\end{array}$ & $\begin{array}{r}12 \\
19 \\
12 \\
13 \\
0\end{array}$ & $\begin{array}{r}43 \\
14 \\
8 \\
2 \\
0\end{array}$ & $\begin{array}{r}14 \\
22 \\
15 \\
16 \\
0\end{array}$ & $\begin{array}{r}3 \\
16 \\
0 \\
0 \\
0\end{array}$ & $\begin{array}{l}4 \\
6 \\
4 \\
5 \\
0\end{array}$ & $\begin{array}{r}10 \\
51 \\
0 \\
0 \\
0\end{array}$ & $\begin{array}{r}13 \\
20 \\
14 \\
14 \\
0\end{array}$ \\
\hline $275 \%$ & & \multicolumn{4}{|c|}{ Time period $\mathbf{I}^{1}$} & \multicolumn{4}{|c|}{ Time period $\mathrm{II}^{\mathrm{I}}$} & \multicolumn{4}{|c|}{ Time period III $^{1}$} \\
\hline 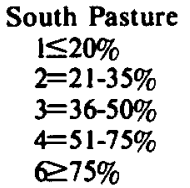 & $\begin{array}{l}11.7 \\
16.2 \\
59.8 \\
12.3 \\
t\end{array}$ & $\begin{array}{r}21 \\
20 \\
17 \\
11 \\
0\end{array}$ & $\begin{array}{r}8 \\
11 \\
41 \\
9 \\
0\end{array}$ & $\begin{array}{r}42 \\
0 \\
6 \\
0 \\
0\end{array}$ & $\begin{array}{r}5.6 \\
7.8 \\
28.7 \\
5.9 \\
0\end{array}$ & $\begin{array}{r}37 \\
11 \\
13 \\
1 \\
0\end{array}$ & $\begin{array}{r}7 \\
10 \\
37 \\
8 \\
0\end{array}$ & $\begin{array}{r}27 \\
13 \\
6 \\
13 \\
0\end{array}$ & $\begin{array}{r}7 \\
10 \\
35 \\
7 \\
0\end{array}$ & $\begin{array}{r}18 \\
28 \\
14 \\
5 \\
0\end{array}$ & $\begin{array}{r}8 \\
10 \\
39 \\
8 \\
0\end{array}$ & $\begin{array}{r}10 \\
6 \\
0 \\
0 \\
0\end{array}$ & $\begin{array}{l}1.9 \\
2.6 \\
9.6 \\
2.0 \\
0\end{array}$ \\
\hline
\end{tabular}

$1=$ significant difference between cows and yearlings $(P<.10)$.

$2=$ No significant difference between cows and yearlings $(P>.10)$

tive humidity increased in zone $\mathbf{I}$, both cows and yearlings moved upslope to zone II.

Ungulates have few mechanisms by which to control body temperature. They can do one or more of the following things to cope with excessive heat: (1) accelerate respiration; (2) consume water; (3) restrict movements or rate of movement; (4) seek more comfortable environmental conditions; or (5) perspire through relatively insufficient apocrine sweat glands. All of these actions tend to reduce the metabolic rate.

Figure 2 shows that the temperature was cooler and the humidity higher in the riparian zone during time period 1 . Both cows and yearlings selected zone I over zone II. Slopes of less than $20 \%$, a cooler microclimate, available water, and available forage quantity and quality apparently combined to produce a more desirable situation.

The dramatic change in both cow and yearling use of plant community types, slope, and zones in time period II was influenced by forage quality and quantity during this period and also by thundershower activity. On the two occasions when thundershowers produced $1.27 \mathrm{~mm}$ and $4.83 \mathrm{~mm}$ of precipitation, both cows and yearlings moved from zone I to zone II.

During period III, both classes of livestock largely avoided zone I. In the north pasture, both cows and yearlings avoided zone I. In the south pasture, however, the yearlings avoided zone I while the cows made disproportionately heavy use of zone I. Some of this change could also be attributed to the two thunderstorms that produced $.5 \mathrm{~mm}$ and $2.29 \mathrm{~mm}$ of precipitation.

During period III, there were no significant differences in mean ambient temperature between weather stations 1 and 3 (Fig. 2) but there was a much higher mean percent relative humidity in the riparian zone. In addition, available forage was greatly reduced in zone I due to grazing and the vegetation in zone II had received little use. The vegetation in zone II was cured, but precipitation had stimulated regrowth and softened the cured vegetation making it more palatable.

Overall, mean-percent relative humidity appeared to have more influence on livestock distribution than temperature. Both cows and yearlings preferred zones where the relative mean humidity was $60-70 \%$ regardless of temperature (Table 4 and Fig. 2). Enrenreich and Bjugstad (1966) explained spring cattle grazing activity in the Missouri Ozarks in a similar manner.

\section{Effect of Slope}

Cows used more slope classes and plant community types than yearlings (Table 3). As slope increased, frequency of use by both livestock classes decreased (Table 3). Phillips (1965), Glendening (1944), Hedrick et al. (1968), and Mueggler (1965) have reported similar results.

Both cows and yearling selected areas with slopes less than $35 \%$ in both pastures. Some 54\% of the north pasture had slopes less than $35 \%$ that received $85 \%$ of the livestock use. In the south pasture, $28 \%$ of the area had slopes of less than $35 \%$ and received

Table 4. The observed and $\chi^{2}$ expected values of cows and yearlings in each zone, in each pasture, in each time period, and the percent of each zone in each pasture.

\begin{tabular}{|c|c|c|c|c|c|c|c|c|c|c|c|c|c|}
\hline \multirow[b]{3}{*}{ Zones } & \multirow{3}{*}{$\begin{array}{l}\text { Percent } \\
\text { of } \\
\text { pasture }\end{array}$} & \multicolumn{4}{|c|}{ Class of livestock } & \multicolumn{4}{|c|}{ Class of livestock } & \multicolumn{4}{|c|}{ Class of livestock } \\
\hline & & \multicolumn{2}{|c|}{ Cows } & \multicolumn{2}{|c|}{ Yearlings } & \multicolumn{2}{|c|}{ Cows } & \multicolumn{2}{|c|}{ Yearlings } & \multicolumn{2}{|c|}{ Cows } & \multicolumn{2}{|c|}{ Yearlings } \\
\hline & & Obs. & $\overline{\text { Exp. }}$ & Obs. & $\overline{\text { Exp. }}$ & Obs. & $\overline{\text { Exp. }}$ & Obs. & Exp. & Obs. & Exp. & Obs. & $\overline{\text { Exp. }}$ \\
\hline & & \multicolumn{4}{|c|}{ Time period $I^{1}$} & \multicolumn{4}{|c|}{ Time period $\mathrm{II}^{2}$} & \multicolumn{4}{|c|}{ Time period III $^{1}$} \\
\hline $\begin{array}{l}\text { North Pasture } \\
\text { I }\end{array}$ & $\begin{array}{r}4 \\
96\end{array}$ & $\begin{array}{l}41 \\
15\end{array}$ & $\begin{array}{r}2 \\
54\end{array}$ & $\begin{array}{l}47 \\
15\end{array}$ & $\begin{array}{r}2.7 \\
59.3\end{array}$ & $\begin{array}{l}29 \\
27\end{array}$ & $\begin{array}{r}2 \\
54\end{array}$ & $\begin{array}{r}59 \\
8\end{array}$ & $\begin{array}{r}2.9 \\
64.1\end{array}$ & $\begin{array}{c}0 \\
19\end{array}$ & $\begin{array}{c}0.8 \\
18.2\end{array}$ & $\begin{array}{c}0 \\
61\end{array}$ & $\begin{array}{r}2.6 \\
58.4\end{array}$ \\
\hline $\begin{array}{l}\text { South Pasture } \\
\text { I } \\
\text { II }\end{array}$ & $\begin{array}{r}5 \\
95\end{array}$ & $\begin{array}{l}39 \\
30\end{array}$ & $\begin{array}{r}\text { me pe } \\
3.2 \\
65.8\end{array}$ & $\begin{array}{r}I^{2} \\
48 \\
0\end{array}$ & $\begin{array}{r}2.3 \\
45.7\end{array}$ & $\begin{array}{r}53 \\
9\end{array}$ & $\begin{array}{c}\text { me per } \\
2.9 \\
59.1\end{array}$ & $\begin{array}{r}\mathrm{II}^{2} \\
0 \\
59\end{array}$ & $\begin{array}{r}2.8 \\
56.2\end{array}$ & $\begin{array}{l}20 \\
45\end{array}$ & $\begin{array}{c}\text { ne peri } \\
3.1 \\
61.9\end{array}$ & $\begin{array}{r}\mathrm{III}^{2} \\
0 \\
16\end{array}$ & $\begin{array}{r}0.75 \\
15.25\end{array}$ \\
\hline
\end{tabular}

$1=$ Significant difference between cows and yearlings $(P>.10)$.

$2=$ Significant difference between cows and yearlings $(P<.10)$. 
$71 \%$ of the livestock use (Table 3).

This is contrary to the observations of Hedrick et al. (1968:4) made under roughly similar conditions in the Blue Mountains. They stated that ... Young animals. . . use[d] these rough timbered areas most efficiently. A ranking to show different classes of cattle in declining order of suitability for these areas is as follows: Steers, replacement heifers, young cows with grazing experience in [the] area as heifers, old cows without calves, and regular cows and calves." No data was presented in support of this contention.

Hickey and Garcia (1964), working with cattle distribution and forage utilization on non-forested ranges in New Mexico, concluded that, "Yearling cattle utilize grasses more uniformly over variable terrain than ... cows with calves. .. . On rough terrain more uniform utilization may be attained by grazing with yearling heifers. ..." Data were presented to support this contention.

There is no satisfactory way to explain the differences in the distribution patterns of cows with calves and yearlings reported here and those reported by Hedrick et al. (1968) and Hickey and Garcia (1964). In future studies, we will pay particular attention to this aspect of livestock behavior.

\section{Water}

Free water was available in zone $I$ and the extreme upper end of the north pasture (zone II) (Fig. 1). Table 5 illustrates the influence of water on the distribution of cows and yearlings during each time period. During time period I, the cows remained closer to water than did yearlings. This can probably be attributed to the cow's greater need for water caused by body size and lactation. In time period II, there was no statistical difference between cows and yearlings, in terms of their distance from water. Their activities and behavior, however, were altered by the thundershower activity. At the beginning of this time period, cows stayed closer to water and then increased their distance from it. However, yearlings distributed themselves closer to the water than cows and maintained that distance throughout the period (Table 5). The yearlings were in the pasture before the thundershower activity, and the cows were present during the thunderstorms.

In time period III, water was ineffective in distributing cows or yearlings. Although there was a difference in how cows and yearling were distributed, they both responded similarly to the progression of the grazing season (Table 5). This could be attributed to the cooler temperatures (which influenced water consumption rates), fall regrowth, softening of the cured forage, and/or a decrease in lactation production by cows.

Water in the upper end of the north pasture (Fig. 1) received little use by either cows or yearlings until time period III. The cows were exposed to the upper water source when they were initially introduced to the pasture. Although it seemed likely that this water source might attract the cows (and away from the riparian zone) for a short time, it did not. The cows were introduced into the pasture at this water source in the late afternoon and by early morning they were in zone I.

Table 5. Mean distance in meters from nearest salt and water source by cows and yearlings.

\begin{tabular}{|c|c|c|c|c|c|c|}
\hline \multirow[b]{2}{*}{ Attractants } & \multicolumn{2}{|c|}{ Time period I } & \multicolumn{2}{|c|}{ Time period II } & \multicolumn{2}{|c|}{ Time period III } \\
\hline & Cows' & Yearlings $^{1}$ & Cows & Yearlings & Cows & Yearlings \\
\hline $\begin{array}{l}\text { North Pasture } \\
\text { Salt }^{2} \\
\text { Water }^{2}\end{array}$ & $\begin{array}{l}832 \\
260\end{array}$ & $\begin{array}{l}806 \\
351\end{array}$ & $\begin{array}{l}754 \\
481\end{array}$ & $\begin{array}{l}897 \\
442\end{array}$ & $\begin{array}{l}442 \\
845\end{array}$ & $\begin{array}{l}390 \\
676\end{array}$ \\
\hline $\begin{array}{l}\text { South Pasture } \\
\text { Salt }^{2}\end{array}$ & $845^{3}$ & $767^{4}$ & 793 & 1027 & 793 & 871 \\
\hline
\end{tabular}

ISignificant difference between time periods I-II, I-III, and II-III $(P<.10)$ for both cow and yearlings.

2Significant differences between cows and yearlings when the 3 periods were pooled. ${ }^{3}$ No difference between time periods $(P>.10)$ for cows.

4Significant difference between time periods, 1-1l. I-III, and II-III $(P>.10)$ for yearlings.
Provision of water is usually considered the most important tool for influencing distribution of livestock (Cook and Jefferies 1963, Glendening 1944, Martin and Ward 1970). Because of the availability of water in the riparian zone and the necessity for cattle to negotiate steep slopes to reach the upper elevation water source, such was not the case here. Findings suggest that water is much less effective for influencing cattle distribution in areas where water is present in the already disproportionately attractive riparian zone.

\section{Salt}

Though there was a difference in the way cows and yearlings distributed themselves in relationship to salt, it was not effective in altering distribution between livestock classes (Table 5). During time period III, the cattle moved from zone I to II. This move put them closer to salt, but they appeared not to be influenced by the salt per se. The behavior in time period III contrasted to that in periods I and II. It was anticipated that salt consumption would be highest during the early grazing season when forage plants were most succulent. Cattle probably choose not to expend the energy necessary to climb out of the canyon bottom to obtain the salt. Once they moved out of the canyon bottom in response to other factors, they did use some salt which is similar to what Cook (1966) found.

These cattle used the salt when convenient but did not alter behavior patterns to obtain it. There did appear to be some relationship between cattle movement and salt use during time period II. This was related to general movements from zone I to II during thundershower activity.

Martin and Ward (1973, p. 96) reached these conclusions:

Placing salt or meal-salt mixture on remote parts of the range where forage is abundant will increase utiliztion of perennial grasses in such areas but will not greatly decrease use on areas closer to water.

Placement of salt or meal-salt alone cannot be expected to cure a serious distribution problem. ...

Skovlin (1965) suggested that range cattle required little supplemental salt in addition to that present in forage, but their appetite compels them to use it as a condiment. Hed rick et al. (1968) contended that salting in other than supplemental forms had little effect on livestock use patterns in mixed coniferous forest types. Morris and Murphy (1972) maintained that salt requirements of cattle have not been demonstrated.

\section{Conclusions}

The following conclusions are preliminary in that the study was conducted for 1 grazing season in 2 pastures. Pasture configuration may also have influenced distributional patterns.

Cows and yearlings concentrated their use in the riparian zone. This resulted from comfort (microclimate), energy conservation, availability of succulent vegetation, or a combination of these factors. Lower temperatures and higher relative humidity occurred in zone $I$ in time periods I and II. Cows used more plant community types regardless of aspect than did yearlings, with concentration on the more productive of these types.

Slopes less than $35 \%$ were preferred by both classes of cattle regardless of pasture aspect. The cows made more use on the steeper slope classes in both pastures, however, than did yearlings.

Salt placement in upper portions of the pastures did not induce cattle to use these areas nor did it reduce cattle concentrations on riparian communities. Manipulation of access to water as a means of controlling cattle use of riparian zones needs further research to determine its effectiveness in increasing livestock distribution.

Leaving a portion of the riparian zone available to cattle exposed a very attractive plant community type of which livestock demonstrated a high preference. Eliminating access to water near this area would probably have lessened the problem of cattle concentrations. 


\section{Recommendations}

Data suggest that because of limited use of slopes over 35\%, a case-by-case determination of cattle stocking rates should be considered.

When forage-rich riparian zones are available at the bottom of narrow canyons, they are attractive to cattle and concentrate their activity. This feature should be carefully considered when preparing a range management plan or implementing practices.

When fencing riparian zones to exclude livestock, care should be taken to insure that all riparian plant community types are included. To eliminate livestock concentrations in the riparian zone it might be better to place the fence on the first flat area above the stream.

Conditions of temperature and relative humidity in late season (period III) produced a less comfortable environment in canyon bottom riparian zones and more comfortable environments on the upslopes. It is possible, therefore, that stocking pastures with riparian zones during the cooler part of the grazing season would lessen cattle impacts.

Cows with calves used more slope classes and more plant communities than did yearlings-i.e., cows can be assumed to have better and more complete utilization of available forage than do yearlings. Cows with calves should be stocked, in prefe rence to or in combination with yea rlings, to increase distribution and, in turn, utilization of forage in pastures with the characteristics of those found in the study area.

In summary, in the study area pastures, inclusion of pastures with riparian zones as separate units in a rotation grazing system and by grazing these pastures late in the grazing season by cows with calves will produce the best use of the upland forage resources. In turn, this treatment should reduce grazing impact on the riparian zone.

\section{Literature Cited}

Ames, C.R. 1977. Wildlife conflicts in riparian management: Grazing. In: Importance, preservation, and management of riparian habitat: a symposium. USDA Forest Serv. Gen. Tech. Rep. RM-43, p. 49-51. Rocky Mountain Forest and Range Exp. Sta., Fort Collins, Colo.

Carothers, S.W. 1977. Importance, preservation, and management of riparian habitats: an overview. In: Importance, preservation, and management of riparian habitat: a symposium. USDA Forest Serv. Gen. Tech. Rep. RM-43, p. 2-4. Rocky Mountain Forest and Range Exp. Sta., Fort Collins, Colo.

Cook, C. Wayne. 1966. Factors affecting utilization of mountain slopes by cattle. J. Range Manage. 19:200-204.

Cook, C. Wayne, and Ned Jefferies. 1963. Better distribution of cattle on mountain ranges. Utah Farm Home Sci. 24:31-34.

Driscoll, Richard S. 1955. A guide to the Starkey Experimental Forest and Range. USDA Forest Serv. Pac. Northwest Forest and Range Exp. Sta., Portland, Ore. 21 p.

Ehrenreich, J.H., and A.J. Bjugstad. 1966. Cattle grazing time is related to temperature and humidity. J. Range Manage. 19:141-142.
Federal Water Pollution Control Act. 1972. Federal Water Pollution Control Act Amendments of 1972. 70 Stat. 498; 84 Stat. 91.33 USC 1151. Public Law 92-500. 92nd Congress, S.2700, 86 Stat. 816-904.

Ganskopp, D.C. 1978. Plant communities and habitat types of the Meadow Creek Experimental Watershed. M.S. Thesis. Oregon State Univ., Corvallis. $151 \mathrm{p}$.

Glendening, G.E. 1944. Some factors affecting cattle use of northern Arizona pine-bunchgrass ranges. USDA Forest Serv. Southwest. Forest and Range Exp. Sta. Res. Pap. No. 6, 9 p. (Now Pac. Southwest. Forest \& Range Exp. Sta., Berkeley, Calif.)

Hall, Frederick C. 1973. Plant communities of the Blue Mountains of eastern Oregon and southeastern Washington. USDA Forest Serv. Pac. Northwest Reg., R6 Area Guide 3-1, 62 p. Portland, Ore.

Hedrick, D.W., J.A. Young, J.A.B. McArthur, and R.F. Keniston. 1968. Effects of forest and grazing practices on mixed coniferous forests of northeastem Oregon. Agr. Exp. Sta. Tech. Bull. No. 103, 24 p. Oreon State Univ., Corvallis.

Hickey, W.C., Jr., and G. Garcia. 1964. Range utilization patterns as affected by fencing and class of livestock. USDA Forest Serv. Res. Note RM-21, 7 p. Rocky Mountain Forest and Range Exp. Sta., Fort Collins, Colo.

Holechek, J.L., M. Vavra, J.M. Skovlin, and R.L. Phillips. 1978. Cattle performance on forested and grassland range. Agr. Exp. Sta. Spec. Rep. 505, 23 p. Oregon State Univ., Corvallis.

Martin, S. Clark, and Donald E. Ward. 1970. Rotating access to water to improve semidesert cattle range near water. J. Range Manage. 23:22-26.

Martin, S. Clark, and Donald E. Ward. 1973. Salt and meal-salt help distribute cattle use on semidesert range. J. Range. 26:94-97.

Maynard, L.A., and J.K. Loosli. 1969. Animal nutrition. McGraw-Hill Book Co., New York. 613 p.

Morris, J.G., and G.W. Murphy. 1972. Sodium requirements of beef calves for growth. In: Western Section, American Society of Animal Science, Proceedings. Banff School of Fine Arts, Banff, Alberta, Canada. p. $401-403$ of 610 pages.

Mueggler, W.F. 1965. Cattle distribution on steep slopes. J. Range Manage. 18:255-257.

Phillips, Thomas A. 1965. The influence of slope gradient, distance from water, and other factors on livest ock distribution on national forest cattle allotments of the intermountain region. USDA Forest Serv. Range Improv. Notes 10:9-19. Intermt. Reg., Ogden, Utah.

Pickford, G.D., and E.H. Reid. 1948. Forage utilization on summer cattle ranges in eastern Oregon. U.S. Dep. Agr. Circ. 796, 27 p.

Skovlin, Jon M. 1965. Improving cattle distribution on western mountain rangelands. USDA Farmers' Bull. No. 2212 . 14 p.

Soil Conservation Service and USDA Forest Service. 1960. Soil survey, Starkey Experimental Forest and Range, Union and Umatilla Counties, Oregon. Soil Conserv. Serv. and USDA Forest Serv., Pac. Northwest For. and Range Exp. Sta. 32 p. mimeo.

Steel, R.G.D., and J.H. Torrie. 1960. Principles and procedures of statistics. McGraw-Hill Book Co., New York. 481 p.

Strickler, G.S. 1965. Soil and vegetation on the Starkey Experimental Forest and Range. Soc. Amer. For. Proc. 1965:27-30.

Thomas, Jack Ward, Chris Maser, and Jon E. Rodiek. 1979. Riparian zones. In: Wildlife habitats in managed forests-the Blue Mountains of Oregon and Washington, edited by Jack Ward Thomas. USDA Forest Serv. Agr. Handb. 553, 512 p. U.S. Gov. Print. Off., Wash. D.C. 